Journal of Organometallic Chemistry, 244 (1983) 247-255

Elsevier Sequoia S.A., Lausanne - Printed in The Netherlands

\title{
REACTIVITY OF THE METAL-METAL-MULTIPLE BOND IN METAL CARBONYL DERIVATIVES
}

\author{
VI *. INVESTIGATION INTO THE REACTION OF $\left[\mathrm{C}_{5} \mathrm{Me}_{5}(\mathrm{CO})_{2} \mathrm{Mo}\right]_{2}$ WITH \\ $\mathrm{CH}_{3} \mathrm{~N}=\mathrm{C}=\mathrm{S}$ : FORMATION AND CRYSTAL STRUCTURE OF \\ $\left(\mathrm{C}_{5} \mathrm{Me}_{5}\right)_{2}(\mathrm{CO})_{4} \mathrm{Mo}_{2}\left(\mu, \eta^{2}-\mathrm{C} \equiv \mathrm{NCH}_{3}\right)$
}

HENRI BRUNNER, HILDEGARD BUCHNER, JOACHIM WACHTER *,

Institut für Anorganische Chemie der Universität Regensburg, Universitätsstrasse 31, D.8400 Regensburg (F.R.G.)

IVAN BERNAL and WOLFGANG H. RIES

Department of Chemistry, University of Houston, Houston, Texas 77004 (U.S.A.)

(Received October 22nd, 1982)

\section{Summary}

The reaction of $\left[\mathrm{C}_{5} \mathrm{Me}_{5}(\mathrm{CO})_{2} \mathrm{Mo}_{2}\right.$ with $\mathrm{CH}_{3} \mathrm{~N}=\mathrm{C}=\mathrm{S}$ gives $\mathrm{C}_{5} \mathrm{Me}_{5}(\mathrm{CO})_{2^{-}}$ $\mathrm{MoS}_{2} \mathrm{CNHCH}_{3}$ and $\left[\mathrm{C}_{5} \mathrm{Me}_{5}(\mathrm{CO})_{2} \mathrm{Mo}_{2}\left(\mu, \eta^{2}-\mathrm{CNCH}_{3}\right)\right.$. The latter compound contains a bridging isonitrile ligand of fluxionial behavior as proved by high temperature ${ }^{1} \mathrm{H}$ NMR spectroscopy. The $\sigma+\pi$ bonded character of the isonitrile bridge was established by $\mathrm{X}$-ray crystallography.

Much attention has been paid to the addition of small donor molecules to the formally unsaturated $\left[\mathrm{C}_{5} \mathrm{H}_{5} \mathrm{Mo}(\mathrm{CO})_{2}\right]_{2}$ [2]. Careful investigations have been carried out recently on the symmetrical addition of allenes [3]. In contrast, relatively little is known about the reaction with heteroallenes, $\mathrm{X}=\mathrm{C}=\mathrm{Y}$. As a first example we showed that $\left(\mathrm{C}_{5} \mathrm{R}_{5}\right)_{2} \mathrm{Mo}_{2}(\mathrm{CO})_{4}\left(\mathrm{R}=\mathrm{H}, \mathrm{CH}_{3}\right)$ reacts with boiling $\mathrm{S}=\mathrm{C}=\mathrm{S}$ to give complexes of the type $\mathrm{C}_{5} \mathrm{R}_{5}(\mathrm{CO})_{3} \mathrm{Mo}-\mathrm{Mo}(\mathrm{CO})_{2}\left(\eta^{2}-\mathrm{CS}_{2}\right) \mathrm{C}_{5} \mathrm{R}_{5}$, containing a nonbridging, terminal $\eta^{2}-\mathrm{CS}_{2}$ ligand [4]. Stimulated by this result, we are using other heteroallenes, e.g. isothiocyanates and carbodiimides. In this paper we report on the reaction of $\left[\mathrm{C}_{5} \mathrm{Me}_{5}(\mathrm{CO})_{2} \mathrm{Mo}_{2}\right.$ with $\mathrm{CH}_{3} \mathrm{~N}=\mathrm{C}=\mathrm{S}$.

\section{Experimental section}

All procedures were carried out under nitrogen with solvents freshly distilled under nitrogen from appropriate drying agents. I was prepared according to a published procedure [5], $\mathrm{CH}_{3} \mathrm{NCS}$ was obtained from Fluka.

* For part V see ref. 1. 
Preparation of $\left[\mathrm{C}_{5} \mathrm{Me}_{5}(\mathrm{CO})_{2} \mathrm{Mo}\right]_{2}\left(\mu, \eta^{2}-\mathrm{CNCH}_{3}\right)$

A mixture of $287 \mathrm{mg}(0.50 \mathrm{mmol})$ of I with $36 \mathrm{mg}(0.50 \mathrm{mmol})$ of $\mathrm{CH}_{3} \mathrm{NCS}$ and $100 \mathrm{ml}$ of toluene was stirred at $100^{\circ} \mathrm{C}$ for $15 \mathrm{~h}$. After concentration of the solvent to $20 \mathrm{ml}$ the solution was transferred to a column $\left(30 \times 3 \mathrm{~cm}, \mathrm{SiO}_{2}\right)$. Using toluene a red band was first eluted, containing $70 \%$ of unreacted starting material. A second red-brown band was chromatographed again with toluene/pentane $(3 / 1)$ to remove the remaining starting material. The red-brown complex III was isolated in $25 \%$ yield with respect to reacted material; it was recrystallized from ether at $-35^{\circ} \mathrm{C}$. A third red-brown band contained complex II.

Analysis of $\left[\mathrm{C}_{5} \mathrm{Me}_{5}(\mathrm{CO})_{2} \mathrm{Mo}_{2}\left(\mu, \eta^{2}-\mathrm{CNCH}_{3}\right)\right.$, (III): Found: $\mathrm{C}, 50.73 ; \mathrm{H}, 5.47 ; \mathrm{N}$, 1.98\%; Molweight (field desorption mass spectroscopy from toluene), 607 (related to ${ }^{92} \mathrm{Mo}$ ). $\mathrm{C}_{26} \mathrm{H}_{33} \mathrm{Mo}_{2} \mathrm{NO}_{4}$ calcd.: C, 50.70; H, 5.40; N, 2.28\%; Molweight 615.4.

Properties: Darkred crystals, mp. $168^{\circ} \mathrm{C}$ (dec.).

\section{$X$-Ray data collection, solution and refinement}

Data were collected as previously described [6]. The instrument was a CAD-4 diffractometer operating on the OS/4 mode. Important crystallographic data collection and processing parameters are listed in Table 1 . From the crystals available only one of marginal quality was found and used but since even proof of structure was desirable given the nature of the reaction studied, a data set was collected.

The Niggli matrix [7] showed the lattice to be end-centered and the distribution of unitary structure factors was that of an acentric space group. The centrosymmetric choice, $C 2 / c$, with $Z=4$ would require the molecule to lie at a special position (with molecular symmetry of either an inversion center or a two-fold axis) neither one of

TABLE 1

SUMMARY OF DATA COLLECTION AND PROCESSING PARAMETERS

Space group

Cell constants

Cell volume

Molecular formula

Molecular weight

Density (calcd.)

Radiation

Absorption coefficient

Data collection range

Scan width

Maximum scan time

Scan speed range

Total data collected

Data with $I>3 \sigma(\mathrm{I})$

Total variables

$\boldsymbol{K}=\Sigma|| \boldsymbol{F}_{\mathbf{0}}|-| \boldsymbol{F}_{\mathrm{c}}|| / \Sigma\left|\boldsymbol{F}_{\mathbf{0}}\right|$

$R_{w}=\left[\Sigma w\left(\left|F_{0}\right|-\left|F_{\mathrm{c}}\right|^{2} / \Sigma w\left|F_{0}\right|^{2}\right]^{1 / 2}\right.$

Weights

Goodness of fit
$C_{c}$

a $16.517(5) \AA$

$b$ 8.754(14) $\AA$

c 21.599(6) $\AA$

B 121.70(2) ${ }^{\circ}$

V 2657.041 $\AA^{3}$

$\mathrm{C}_{26} \mathrm{H}_{33} \mathrm{Mo}_{2} \mathrm{NO}_{4}$

615.444

$\rho 1.5383 \mathrm{~g} \mathrm{~cm}^{-3}$

$\operatorname{Mo}-K_{\alpha}(\lambda 0.71609 \AA)$

$\mu 9.50 \mathrm{~cm}^{-1}$

$4^{\circ} \leq 2 \theta \leq 50^{\circ}$

$\Delta \theta=(1.00+0.35 \tan \theta)^{\circ}$

$240 \mathrm{sec}$

0.38 to $5.03^{\circ} \mathrm{min}^{-1}$

2560

971

100

0.0604

0.0586

$w=0.9787 / \sigma^{2}(F)$

1.66 
which is possible for this substance unless there is crystallographic disorder in the lattice. Since we found no evidence of such disorder, the completely consistent assignment of space group $C_{c}$ was made. The two independent Mo atoms were found in a Patterson map and the rest of the non-hydrogen atoms in subsequent Fourier maps. Given the large number of atoms for the number of observed data, the $\mathrm{C}_{5} \mathrm{Me}_{5}$ ring atoms were refined as rigid bodies using DFIX in SHELX-76 [8] (see Table 4). Under these conditions, the refinement proceeded smoothly to the values listed in Table 1.

\section{Results and discussion}

Whereas the reaction of $\left[\mathrm{C}_{5} \mathrm{H}_{5}(\mathrm{CO})_{2} \mathrm{Mo}\right]_{2}$ with $\mathrm{CH}_{3} \mathrm{NCS}$ gives as the only isolable product traces of the dithiocarbamato complex $\mathrm{C}_{5} \mathrm{H}_{5}(\mathrm{CO})_{2} \mathrm{MoS}_{2} \mathrm{CNHCH}_{3}$ [9], $\left[\mathrm{C}_{5} \mathrm{Me}_{5}(\mathrm{CO})_{2} \mathrm{Mo}\right]_{2}$ gives several products, depending on the reaction conditions. With a tenfold excess of $\mathrm{CH}_{3} \mathrm{NCS}$ in toluene at $45^{\circ} \mathrm{C}$, the only product is $\mathrm{C}_{5} \mathrm{Me}_{5}(\mathrm{CO})_{2} \mathrm{MoS}_{2} \mathrm{CNHCH}_{3}$ (II), which can be characterized by means of IR $\left(\nu(\mathrm{NH}) 3370, \nu(\mathrm{CO}) 1925,1810 \mathrm{~cm}^{-1}\right)$ and ${ }^{1} \mathrm{H}$ NMR spectroscopy $\left(\delta\left(\mathrm{CH}_{3}\right)^{1} 1.83\right.$, $\left.\delta\left(\mathrm{NCH}_{3}\right)^{2} 2.98 \mathrm{ppm}\right)$. This product may arise from sulfur loss of another ligand, followed by sulfur insertion. The resulting dithiocarbonimidato complex $[10,11]$ formally requires protonation in order to stabilize the $\mathrm{Cp}(\mathrm{CO})_{2}$ Mo fragment as a three electron donor.

The same product is formed in a similar experiment at $100^{\circ} \mathrm{C}$ (ratio metal/ligand $1 / 10$ ), accompanied by several by-products of general composition $\left(\mathrm{C}_{5} \mathrm{Me}_{5}\right)_{2^{-}}$ $\mathrm{Mo}_{2}\left(\mathrm{CH}_{3} \mathrm{NCS}\right)_{2} \mathrm{~S}_{2}$, the structures of which are still unclear [12]. If the same reaction is carried out with a metal/ligand ratio of $1 / 1$, in addition to complex II the red-brown complex III can be isolated (Scheme 1). Its composition is confirmed by elemental analysis and mass spectrum. From the IR spectrum there is evidence for a bridging isonitrile ligand $\left(\nu(\mathrm{CN}) 1725 \mathrm{~cm}^{-1}\right)$, whereas the terminal $\mathrm{CO}$ region shows four absorptions. The ${ }^{1} \mathrm{H}$ NMR spectrum (Table 2) exhibits one signal for the

$$
\left(\mathrm{C}_{5} \mathrm{Me}_{5}\right)_{2} \mathrm{MO}_{2}(\mathrm{CO})_{4}
$$

(I)

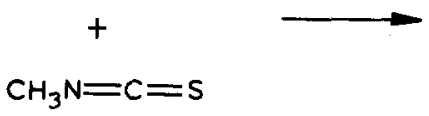

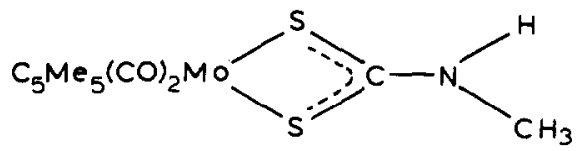

(II)

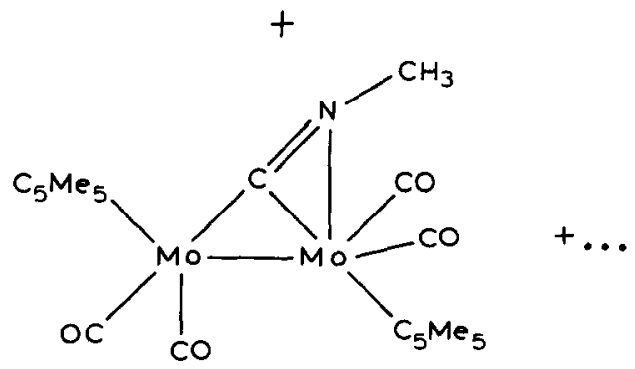


TABLE 2

IR (KBr) AND 'H NMR SPECTRA OF COMPOUNDS II AND III

\begin{tabular}{|c|c|c|c|c|c|c|c|}
\hline \multicolumn{5}{|c|}{ IR $\left(\mathrm{cm}^{-1}\right)$} & \multicolumn{3}{|l|}{${ }^{1} \mathrm{H}$ NMR (ppm) ${ }^{a}$} \\
\hline & $\nu(\mathrm{NH})$ & $\nu(\mathrm{CO})$ & $\nu(\mathrm{C}-\mathrm{N})$ & $\nu(\mathrm{N}-\mathrm{C}-\mathrm{S})$ & $\begin{array}{l}\delta\left(\mathrm{NCH}_{3}\right) \\
\left(\mathrm{J}\left(\mathrm{NH}-\mathrm{CH}_{3}\right)\right)^{b}\end{array}$ & $\delta\left(\mathrm{CH}_{3}\right)$ & Solvent \\
\hline II & $3370 \mathrm{~m}$ & $1925 \mathrm{~s}, 1810 \mathrm{vs}$ & & $1515 \mathrm{~m}$ & $\begin{array}{l}{ }^{2} 2.98 \\
(6.0)\end{array}$ & ${ }^{1} 1.83$ & $\mathrm{CDCl}_{3}$ \\
\hline \multirow[t]{2}{*}{ III } & & $\begin{array}{l}1947 \mathrm{~s}, 1900 \mathrm{vs} \\
1863 \mathrm{vs}, 1820 \mathrm{~s}\end{array}$ & $1725 \mathrm{~m}$ & & ${ }^{3} 3.65$ & ${ }^{1} 1.94,{ }^{1} 1.84$ & $\mathrm{CDCl}_{3}$ \\
\hline & & & & & ${ }^{1} 3.0$ & ${ }^{1} 1.55,{ }^{1} 1.66$ & Toluene- $d_{8}$ \\
\hline
\end{tabular}

${ }^{a} \mathrm{i}-\left(\mathrm{CH}_{3}\right)_{4} \mathrm{Si}$; Varian T-60 instrument. ${ }^{b}$ The NH proton is not detectable.

$\mathrm{N}-\mathrm{CH}_{3}$ group, but two resonances for the methyl groups of the cyclopentadienyl ring. The inequivalent character of these groups is a function of the temperature: if the sample is warmed up in toluene- $d_{8}$, broadening of the signals occurs and coalescence is observed at about $82^{\circ} \mathrm{C}$. Above $90^{\circ} \mathrm{C}$ there is only one peak. This process is reversible, but superceded by partial decomposition which prevents quantitative analysis.

The spectroscopic data are consistent with a formulation as a bridged isonitrile complex, in which asymmetry is caused by a $\sigma+\pi$ coordination of the bridging ligand $[13,14]$. However, the coalescence temperature is considerably higher (about $100^{\circ} \mathrm{C}$ ) than in complexes incorporating the semibridging cyanide or cyanoamide ligands [13], which are bonded in the same $\sigma+\pi$ fashion.

In order to confirm our structural proposal and to study the influence of the pentamethyl groups on the geometry of the molecule we decided to do an X-ray examination of the structure. While this study was being completed, Adams and coworkers [14] published a different synthesis and a structural study of the related isonitrile derivative $\left(\mathrm{C}_{5} \mathrm{H}_{5}\right)_{2} \mathrm{Mo}_{2}(\mathrm{CO})_{4}\left(\mu, \eta^{2}-\mathrm{CNC}_{6} \mathrm{H}_{5}\right)$ (IV), which differs from III in having $\mathrm{C}_{5} \mathrm{H}_{5}$ and $\mathrm{CN}-\mathrm{C}_{6} \mathrm{H}_{5}$ groups instead of $\mathrm{C}_{5} \mathrm{Me}_{5}$ and $\mathrm{CN}-\mathrm{Me}$. Since these crystals were, obviously, much better and the quality of refinement superior, we were pleased to note that our results are in good agreement with theirs.

\section{Description of the molecule}

The atomic parameters, bond distances and bond angles are given in Tables 3-5. Figures 1-3 show an ORTEP, a stereoplot and a packing diagram of III.

If we look first at the core of the molecule, we find that the distances and angles associated with the $\left(\mathrm{Cp}_{2} \mathrm{Mo}(1) \mathrm{Mo}(2) \mathrm{CN}-\mathrm{C}\right)$ core of III and IV (Table 6) are of the same order. Therefore, despite our much larger e.s.d.'s a consistent picture of the core of these two molecules emerges from the above comparisons of bond distances and angles and the accurate and precise determination of Adams et al. [14] lends credibility to our, otherwise, low-precision determination. Clearly evident in both studies is the dual $\sigma+\pi$ role played by the asymmetric bridging isonitrile with $\sigma$ Mo-C(N) distances of 1.93(4) (III) and $1.942(2) \AA$ (IV) and $\pi$ Mo-C(N) distances of 2.21(4) (III) and 2.247(2) $\AA$ (IV). Given these broad areas of agreement, the discussion of the meaning of these parameters in the report of Adams [14] makes further comments by us superfluous. 


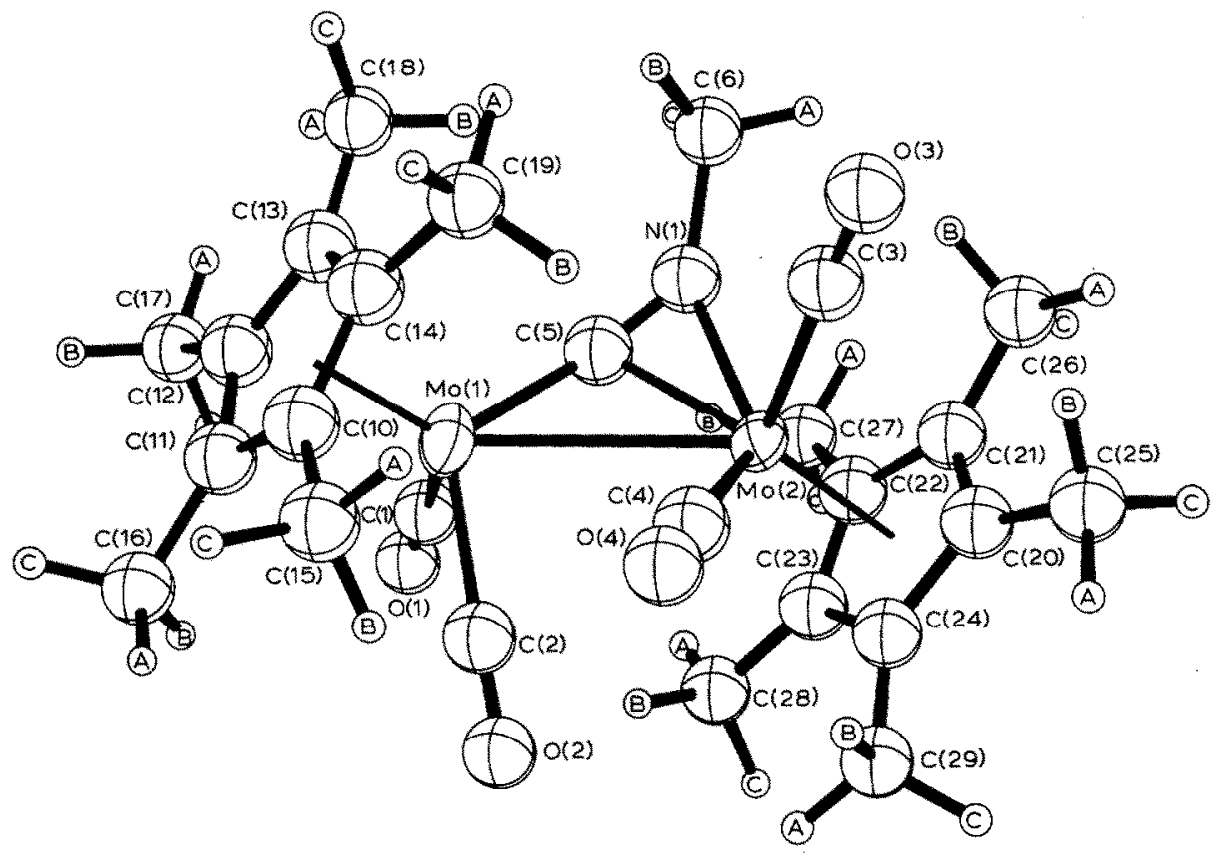

Fig. 1. ORTEP of III showing the numbering system used.
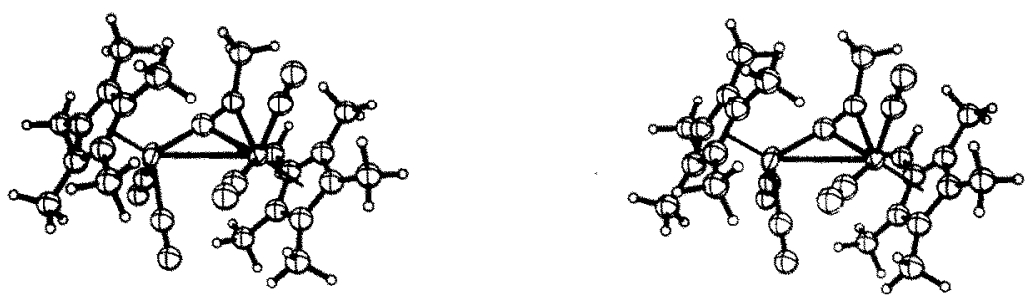

Fig. 2. Stereo pair of III.
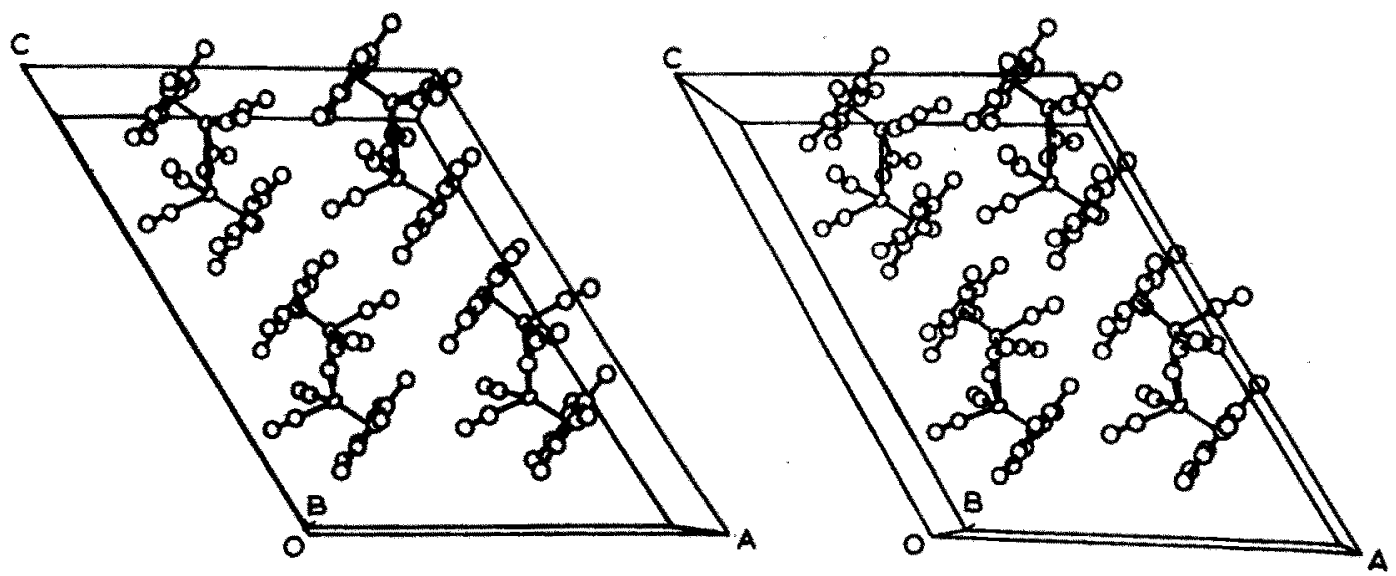

Fig. 3. Packing diagram of III. 
TABLE 3

ATOMIC COORDINATES AND THERMAL PARAMETERS $(\times 1000)$

\begin{tabular}{|c|c|c|c|c|c|c|c|c|c|}
\hline Atom & $x / a$ & $y / b$ & $z / c$ & $U_{11}$ & $U_{22}$ & $U_{33}$ & $U_{12}$ & $U_{13}$ & $U_{23}$ \\
\hline $\operatorname{Mo}(1)$ & $0.2890(0)$ & $0.0370(5)$ & $0.3070(0)$ & $62(4)$ & $92(4)$ & $43(4)$ & $5(3)$ & $36(3)$ & $1(3)$ \\
\hline $\operatorname{Mo}(2)$ & $0.3971(2)$ & $0.0219(5)$ & $0.4828(2)$ & $42(3)$ & $71(3)$ & $44(3)$ & $14(3)$ & $26(3)$ & $5(3)$ \\
\hline$O(1)$ & $0.071(1)$ & $-0.007(4)$ & $0.238(2)$ & $169(18)$ & & & & & \\
\hline$O(2)$ & $0.219(3)$ & $0.338(3)$ & $0.342(2)$ & $139(16)$ & & & & & \\
\hline$O(3)$ & $0.613(1)$ & $0.060(3)$ & $0.555(2)$ & $92(11)$ & & & & & \\
\hline$O(4)$ & $0.486(2)$ & $0.320(2)$ & $0.464(2)$ & $101(11)$ & & & & & \\
\hline$N(1)$ & $0.373(2)$ & $-0.196(4)$ & $0.431(2)$ & $77(10)$ & & & & & \\
\hline$C(1)$ & $0.153(1)$ & $-0.009(3)$ & $0.266(2)$ & $42(9)$ & & & & & \\
\hline$C(2)$ & $0.227(3)$ & $0.214(5)$ & $0.324(2)$ & $185(28)$ & & & & & \\
\hline $\mathrm{C}(3)$ & $0.533(1)$ & $-0.039(6)$ & $0.534(4)$ & $185(32)$ & & & & & \\
\hline$C(4)$ & $0.443(2)$ & $0.217(2)$ & $0.465(2)$ & $50(11)$ & & & & & \\
\hline$C(5)$ & $0.324(3)$ & $-0.115(4)$ & $0.382(2)$ & $80(12)$ & & & & & \\
\hline$C(6)$ & $0.426(3)$ & $-0.347(5)$ & $0.443(3)$ & $128(17)$ & & & & & \\
\hline$C(10)$ & $0.383(1)$ & $0.179(1)$ & $0.271(1)$ & $45(8)$ & & & & & \\
\hline$C(11)$ & $0.290(1)$ & $0.155(1)$ & $0.209(1)$ & $51(9)$ & & & & & \\
\hline$C(12)$ & $0.276(1)$ & $-0.005(1)$ & $0.197(1)$ & $69(10)$ & & & & & \\
\hline$C(13)$ & $0.360(1)$ & $-0.080(1)$ & $0.252(1)$ & $85(11)$ & & & & & \\
\hline$C(14)$ & $0.426(1)$ & $0.034(1)$ & $0.297(1)$ & $37(9)$ & & & & & \\
\hline$C(15)$ & $0.427(1)$ & $0.331(1)$ & $0.302(1)$ & $92(12)$ & & & & & \\
\hline$C(16)$ & $0.220(1)$ & $0.277(1)$ & $0.164(1)$ & $192(24)$ & & & & & \\
\hline$C(17)$ & $0.188(1)$ & $-0.082(1)$ & $0.138(1)$ & $156(19)$ & & & & & \\
\hline$C(18)$ & $0.376(1)$ & $-0.249(1)$ & $0.260(1)$ & $144(19)$ & & & & & \\
\hline$C(19)$ & $0.524(1)$ & $0.006(1)$ & $0.361(1)$ & $81(9)$ & & & & & \\
\hline$C(20)$ & $0.419(1)$ & $0.057(2)$ & $0.597(1)$ & $43(8)$ & & & & & \\
\hline$C(21)$ & $0.383(1)$ & $-0.094(2)$ & $0.577(1)$ & $45(8)$ & & & & & \\
\hline$C(22)$ & $0.290(1)$ & $-0.086(2)$ & $0.515(1)$ & $40(8)$ & & & & & \\
\hline $\mathrm{C}(23)$ & $0.267(1)$ & $0.071(2)$ & $0.497(1)$ & $73(14)$ & & & & & \\
\hline $\mathrm{C}(24)$ & $0.347(1)$ & $0.159(2)$ & $0.548(1)$ & $47(8)$ & & & & & \\
\hline$C(25)$ & $0.516(1)$ & $0.101(2)$ & $0.659(1)$ & $90(12)$ & & & & & \\
\hline$C(26)$ & $0.436(1)$ & $-0.238(2)$ & $0.615(1)$ & $96(12)$ & & & & & \\
\hline $\mathrm{C}(27)$ & $0.225(1)$ & $-0.218(2)$ & $0.476(1)$ & $92(11)$ & & & & & \\
\hline$C(28)$ & $0.175(1)$ & $0.133(2)$ & $0.436(1)$ & $132(15)$ & & & & & \\
\hline $\mathrm{C}(29)$ & $0.355(1)$ & $0.330(2)$ & $0.549(1)$ & $122(14)$ & & & & & \\
\hline $\mathrm{H}(6 \mathrm{~A})$ & $0.445(3)$ & $-0.429(5)$ & $0.486(3)$ & $140(0)$ & & & & & \\
\hline $\mathrm{H}(6 \mathrm{~B})$ & $0.485(3)$ & $-0.334(5)$ & $0.435(3)$ & $140(0)$ & & & & & \\
\hline $\mathrm{H}(6 \mathrm{C})$ & $0.364(3)$ & $-0.387(5)$ & $0.393(3)$ & $140(0)$ & & & & & \\
\hline$H(15 A)$ & $0.498(1)$ & $0.314(1)$ & $0.349(1)$ & $140(0)$ & & & & & \\
\hline$H(15 B)$ & $0.385(1)$ & $0.391(1)$ & $0.319(1)$ & $140(0)$ & & & & & \\
\hline$H(15 C)$ & $0.431(1)$ & $0.397(1)$ & $0.262(1)$ & $140(0)$ & & & & & \\
\hline$H(16 A)$ & $0.250(1)$ & $0.387(1)$ & $0.186(1)$ & $140(0)$ & & & & & \\
\hline$H(16 B)$ & $0.156(1)$ & $0.262(1)$ & $0.166(1)$ & $140(0)$ & & & & & \\
\hline $\mathrm{H}(16 \mathrm{C})$ & $0.202(1)$ & $0.268(1)$ & $0.109(1)$ & $140(0)$ & & & & & \\
\hline$H(17 A)$ & $0.198(1)$ & $-0.204(1)$ & $0.143(1)$ & $140(0)$ & & & & & \\
\hline H(17B) & $0.174(1)$ & $-0.045(1)$ & $0.086(1)$ & $140(0)$ & & & & & \\
\hline$H(17 C)$ & $0.128(1)$ & $-0.052(1)$ & $0.143(1)$ & $140(0)$ & & & & & \\
\hline $\mathrm{H}(18 \mathrm{~A})$ & $0.314(1)$ & $-0.307(1)$ & $0.218(1)$ & $140(0)$ & & & & & \\
\hline $\mathrm{H}(18 \mathrm{~B})$ & $0.390(1)$ & $-0.285(1)$ & $0.313(1)$ & $140(0)$ & & & & & \\
\hline$H(18 C)$ & $0.436(1)$ & $-0.278(1)$ & $0.255(1)$ & $140(0)$ & & & & & \\
\hline $\mathrm{H}(19 \mathrm{~A})$ & $0.538(1)$ & $-0.116(1)$ & $0.368(1)$ & $140(0)$ & & & & & \\
\hline$H(19 B)$ & $0.530(1)$ & $0.053(1)$ & $0.409(1)$ & $140(0)$ & & & & & \\
\hline $\mathrm{H}(19 \mathrm{C})$ & $0.576(1)$ & $0.060(1)$ & $0.352(1)$ & $140(0)$ & & & & & \\
\hline $\mathrm{H}(25 \mathrm{~A})$ & $0.523(1)$ & $0.223(2)$ & $0.661(1)$ & $140(0)$ & & & & & \\
\hline
\end{tabular}


TABLE 3 (continued)

\begin{tabular}{|c|c|c|c|c|c|c|c|c|c|}
\hline Atom & $x / a$ & $y / b$ & $z / c$ & $U_{11}$ & $U_{22}$ & $U_{33}$ & $U_{12}$ & $U_{13}$ & $U_{23}$ \\
\hline$H(25 B)$ & $0.570(1)$ & $0.050(2)$ & $0.652(1)$ & $140(0)$ & & & & & \\
\hline $\mathrm{H}(25 \mathrm{C})$ & $0.524(1)$ & $0.060(2)$ & $0.710(1)$ & $140(0)$ & & & & & \\
\hline$H(26 A)$ & $0.506(1)$ & $-0.210(2)$ & $0.660(1)$ & $140(0)$ & & & & & \\
\hline$H(26 B)$ & $0.442(1)$ & $-0.309(2)$ & $0.576(1)$ & $140(0)$ & & & & & \\
\hline$H(26 C)$ & $0.397(1)$ & $-0.299(2)$ & $0.634(1)$ & $140(0)$ & & & & & \\
\hline$H(27 A)$ & $0.261(1)$ & $-0.324(2)$ & $0.502(1)$ & $140(0)$ & & & & & \\
\hline $\mathrm{H}(27 \mathrm{~B})$ & $0.207(1)$ & $-0.219(2)$ & $0.420(1)$ & $140(0)$ & & & & & \\
\hline$H(27 C)$ & $0.161(1)$ & $-0.209(2)$ & $0.478(1)$ & $140(0)$ & & & & & \\
\hline $\mathrm{H}(28 \mathrm{~A})$ & $0.127(1)$ & $0.039(2)$ & $0.407(1)$ & $140(0)$ & & & & & \\
\hline $\mathrm{H}(28 \mathrm{~B})$ & $0.188(1)$ & $0.197(2)$ & $0.399(1)$ & $140(0)$ & & & & & \\
\hline $\mathrm{H}(28 \mathrm{C})$ & $0.143(1)$ & $0.207(2)$ & $0.457(1)$ & $140(0)$ & & & & & \\
\hline$H(29 A)$ & $0.289(1)$ & $0.377(2)$ & $0.505(1)$ & $140(0)$ & & & & & \\
\hline $\mathrm{H}(29 \mathrm{~B})$ & $0.413(1)$ & $0.363(2)$ & $0.542(1)$ & $140(0)$ & & & & & \\
\hline$H(29 C)$ & $0.367(1)$ & $0.373(2)$ & $0.600(1)$ & $140(0)$ & & & & & \\
\hline
\end{tabular}

Even though the $\mathrm{M}-\mathrm{C} \equiv \mathrm{O}$ angles in III $\left(158-168^{\circ}\right)$ are found to be smaller than those given for IV $\left(174-179^{\circ}\right)$ this does not seem to be significant with respect to the e.s.d.'s and should mainly be caused by the poor quality of the crystal. This could be valid, in addition, for the bending of the $\mathrm{C}=\mathrm{N}-\mathrm{CH}_{3}$ moiety away from the $\mathrm{C}_{5}\left(\mathrm{CH}_{3}\right)_{5}$ ring $\mathrm{C}(20) \rightarrow \mathrm{C}(29)$ and out of the plane defined by $\mathrm{Mo}(1), \mathrm{Mo}(2)$ and $\mathrm{C}(5)(0.41$ and $1.33 \AA$ for $\mathrm{N}(1)$ and $\mathrm{C}(6)$, respectively). But as on the other hand a position of $\mathrm{C}(6)$ coplanar with $\mathrm{Mo}(1)-\mathrm{C}(5)-\mathrm{Mo}(2)$ would lead to unacceptable short contacts (C...C ca. $2.50 \AA, \mathrm{H} \cdots \mathrm{H}$ even worse) the deviation from planarity reduces those unfavorable interactions and should be regarded as significant. The same distortion is found in the Adam's molecule but to a smaller degree (0.193 and $0.760 \AA$ for $N$ and $C(31)$ ), probably due to the less severe steric interactions, and seems inherent for $\mu, \eta^{2}$-isonitrile complexes.

In summary the reaction of $\left[\mathrm{C}_{5} \mathrm{Me}_{5}(\mathrm{CO})_{2} \mathrm{Mo}_{2}\right.$ with $\mathrm{S}=\mathrm{C}=\mathrm{NCH}_{3}$ is comparable

\section{TABLE 4}

INTRAMOLECULAR DISTANCES $(\dot{\mathrm{A}})$ FOR $\left[\eta-\mathrm{C}_{5} \mathrm{Me}_{5}(\mathrm{CO})_{2} \mathrm{Mo}\right]_{2}\left(\mu, \eta^{2}-\mathrm{CNCH}_{3}\right)$

\begin{tabular}{llll}
\hline $\mathrm{Mo}(1)-\mathrm{Mo}(2)$ & $3.240(3)$ & $\mathrm{Mo}(2)-\mathrm{C}(3)$ & $1.98(1)$ \\
$\mathrm{Mo}(1)-\mathrm{C}(1)$ & $1.97(1)$ & $\mathrm{Mo}(2)-\mathrm{C}(4)$ & $1.98(1)$ \\
$\mathrm{Mo}(1)-\mathrm{C}(2)$ & $2.00(1)$ & $\mathrm{Mo}(2)-\mathrm{C}(5)$ & $2.21(4)$ \\
$\mathrm{Mo}(1)-\mathrm{C}(5)$ & $1.93(4)$ & $\mathrm{Mo}(2)-\mathrm{N}(1)$ & $2.14(3)$ \\
$\mathrm{Mo}(1)-\mathrm{C}(10)$ & $2.42(2)$ & $\mathrm{Mo}(2)-\mathrm{C}(20)$ & $2.32(2)$ \\
$\mathrm{Mo}(1)-\mathrm{C}(11)$ & $2.36(2)$ & $\mathrm{Mo}(2)-\mathrm{C}(21)$ & $2.39(2)$ \\
$\mathrm{Mo}(1)-\mathrm{C}(12)$ & $2.29(2)$ & $\mathrm{Mo}(2)-\mathrm{C}(22)$ & $2.42(2)$ \\
$\mathrm{Mo}(1)-\mathrm{C}(13)$ & $2.31(2)$ & $\mathrm{Mo}(2)-\mathrm{C}(23)$ & $2.37(2)$ \\
$\mathrm{Mo}(1)-\mathrm{C}(14)$ & $2.39(2)$ & $\mathrm{Mo}(2)-\mathrm{C}(24)$ & $2.31(2)$ \\
$\mathrm{N}(1)-\mathrm{C}(5)$ & $1.17(3)$ & $\mathrm{C}(3)-\mathrm{O}(3)$ & $1.16(1)$ \\
$\mathrm{N}(1)-\mathrm{C}(6)$ & $1.53(5)$ & $\mathrm{C}(4)-\mathrm{O}(4)$ & $1.16(1)$ \\
$\mathrm{C}(1)-\mathrm{O}(1)$ & $1.17(1)$ & $\mathrm{Mo}(2)-\mathrm{Cen}(2)$ & $2.03(2)$ \\
$\mathrm{C}(2)-\mathrm{O}(2)$ & $1.18(2)$ & & \\
$\mathrm{Mo}(1)-\mathrm{Cen}(1)$ & $2.02(2)$ & &
\end{tabular}

Distances in idealized rigid bodies for pentamethyl-Cp's are $d(\mathrm{CC})($ ring) $1.420, d(\mathrm{CC})(\mathrm{exo}) 1.500, d(\mathrm{CH})$ $1.08 \AA$ 


\section{TABLE 5}

INTRAMOLECULAR ANGLES $\left(^{\circ}\right)$ FOR $\left[\eta-\mathrm{C}_{5} \mathrm{Me}_{5}(\mathrm{CO})_{2} \mathrm{Mo}\right]_{2}\left(\mu, \eta^{2}-\mathrm{CNCH}_{3}\right)$

\begin{tabular}{|c|c|c|c|}
\hline $\mathrm{Mo}(2)-\mathrm{Mo}(1)-\mathrm{C}(1)$ & $108(1)$ & $\mathrm{Mo}(1)-\mathrm{Mo}(2)-\mathrm{C}(3)$ & $116(3)$ \\
\hline $\mathrm{Mo}(2)-\mathrm{Mo}(1)-\mathrm{C}(2)$ & $80(1)$ & $\mathrm{Mo}(1)-\mathrm{Mo}(2)-\mathrm{C}(4)$ & $77(1)$ \\
\hline $\mathrm{Mo}(2)-\mathrm{Mo}(1)-\mathrm{C}(5)$ & $42(1)$ & $\mathrm{Mo}(1)-\mathrm{Mo}(2)-\mathrm{C}(5)$ & $36(1)$ \\
\hline $\operatorname{Mo}(2)-\operatorname{Mo}(1)-\operatorname{Cen}(1)$ & $128(1)$ & $\operatorname{Mo}(1)-M o(2)-N(1)$ & $65(1)$ \\
\hline$C(1)-M o(1)-C(2)$ & $71(2)$ & $\operatorname{Mo}(1)-\operatorname{Mo}(2)-\operatorname{Cen}(2)$ & $129(1)$ \\
\hline $\mathrm{C}(1)-\mathrm{Mo}(1)-\mathrm{C}(5)$ & $90(2)$ & $\mathrm{C}(3)-\mathrm{Mo}(2)-\mathrm{C}(4)$ & $85(2)$ \\
\hline $\mathrm{C}(1)-\mathrm{Mo}(1)-\mathrm{Cen}(1)$ & $123(2)$ & $\mathrm{C}(3)-\mathrm{Mo}(2)-\mathrm{C}(5)$ & $106(3)$ \\
\hline$C(2)-M o(1)-C(5)$ & $110(2)$ & $C(3)-M o(2)-N(1)$ & $84(2)$ \\
\hline $\mathrm{C}(2)-\mathrm{Mo}(1)-\mathrm{Cen}(1)$ & $122(2)$ & $\mathrm{C}(3)-\mathrm{Mo}(2)-\mathrm{Cen}(2)$ & $114(3)$ \\
\hline$C(5)-M o(1)-C e n(1)$ & $125(2)$ & $\mathrm{C}(4)-\mathrm{Mo}(2)-\mathrm{C}(5)$ & $110(1)$ \\
\hline $\mathrm{Mo}(1)-\mathrm{C}(1)-\mathrm{O}(1)$ & $167(3)$ & $\mathrm{C}(4)-\mathrm{Mo}(2)-\mathrm{N}(1)$ & $130(1)$ \\
\hline $\mathrm{Mo}(1)-\mathrm{C}(2)-\mathrm{O}(2)$ & $158(5)$ & $C(4)-M o(2)-C e n(2)$ & $119(2)$ \\
\hline $\mathrm{Mo}(2)-\mathrm{C}(3)-\mathrm{O}(3)$ & $168(7)$ & $\mathrm{C}(5)-\mathrm{Mo}(2)-\mathrm{N}(1)$ & $31(1)$ \\
\hline $\mathrm{Mo}(2)-\mathrm{C}(4)-\mathrm{O}(4)$ & $168(3)$ & $\mathrm{C}(5)-\mathrm{Mo}(2)-\mathrm{Cen}(2)$ & $118(2)$ \\
\hline $\mathrm{Mo}(1)-\mathrm{C}(5)-\mathrm{Mo}(2)$ & $103(1)$ & $\mathrm{N}(1)-\mathrm{Mo}(2)-\operatorname{Cen}(2)$ & $110(2)$ \\
\hline$M o(1)-C(5)-N(1)$ & $158(3)$ & & \\
\hline $\mathrm{Mo}(2)-\mathrm{C}(5)-\mathrm{N}(1)$ & $71(2)$ & & \\
\hline$C(5)-N(1)-M o(2)$ & $78(2)$ & & \\
\hline$C(5)-N(1)-C(6)$ & $138(3)$ & & \\
\hline $\operatorname{Mo}(2)-N(1)-C(6)$ & $139(2)$ & & \\
\hline
\end{tabular}

to the disproportionation reactions of other heteroallenes $X=C=Y[10,15]$. However, the resulting $\mathrm{X}_{2} \mathrm{CY}$ and $\mathrm{CY}$ fragments are in the present case transferred to molecules of completely different character (mononuclear vs. binuclear) with $\mathrm{C}_{5} \mathrm{Me}_{5}(\mathrm{CO})_{2} \mathrm{MoS}_{2} \mathrm{CNHCH}_{3}$ (II), and $\left[\mathrm{C}_{5} \mathrm{Me}_{5}(\mathrm{CO})_{2} \mathrm{Mo}\right]_{2}\left(\mu, \eta^{2}-\mathrm{CNCH}_{3}\right)$ (III), as the final products.

\section{TABLE 6}

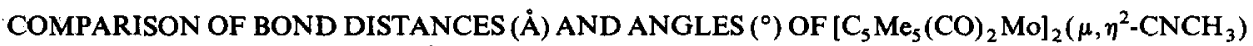
(III) WITH $\left[\mathrm{C}_{5} \mathrm{H}_{5}(\mathrm{CO})_{2} \mathrm{Mo}_{2}\left(\mu, \eta^{2}-\mathrm{CNC}_{6} \mathrm{H}_{5}\right)\right.$ (IV) [14]

\begin{tabular}{lcc}
\hline & III & IV \\
\hline Distances & & \\
Mo-C(N) & $2.21(4)$ & $2.247(2)$ \\
Mo-N(CN) & $1.93(4)$ & $1.942(2)$ \\
Mo-C(Cp) & $2.14(3)$ & $2.207(2)$ \\
Angles & $2.29-2.42$ & $2.30-2.40$ \\
Mo-N-C & & \\
Mo-C-N & $139(2)$ & $144.4(2)$ \\
& $158(3)$ & $167.7(2)$ \\
Mo-Mo-C & $71(2)$ & $72.0(1)$ \\
Mo-Mo-N & $36(1)$ & $36.55(6)$ \\
C-N-C & $65(1)$ & $68.69(5)$ \\
\hline
\end{tabular}

${ }^{a} \mathrm{Mo}(2)-\mathrm{N}(1)-\mathrm{C}(6)$ (III) vs. $\mathrm{Mo}(1)-\mathrm{N}-\mathrm{C}(31)$ (IV). ${ }^{b} \mathrm{Mo}(1)-\mathrm{C}(5)-\mathrm{N}(1)$ (III) vs. $\mathrm{Mo}(2)-\mathrm{C}(5)-\mathrm{N}$ (IV) and $\mathrm{Mo}(2)-\mathrm{C}(5)-\mathrm{N}(1)$ (III) vs. $\mathrm{Mo}(1)-\mathrm{C}(5)-\mathrm{N}$ (IV), respectively. ${ }^{c} \mathrm{Mo}(1)-\mathrm{Mo}(2)-\mathrm{C}$ (5) (III) vs. $\mathrm{Mo}(2)-\mathrm{Mo}(1)-\mathrm{C}(5)$ (IV). ${ }^{d} \mathrm{Mo}(1)-\mathrm{Mo}(2)-\mathrm{N}(1)$ (III) vs. $\mathrm{Mo}(2)-\mathrm{Mo}(1)-\mathrm{N}$ (IV). ${ }^{e} \mathrm{C}(5)-\mathrm{N}(1)-\mathrm{C}(6)$ (III) vs. $\mathrm{C}(5)-\mathrm{N}-\mathrm{C}(31)$ (IV). 


\section{Acknowledgement}

One of the authors (W.H.R.) is grateful for a NATO grant.

\section{References}

1 H. Brunner, J. Wachter and H. Wintergerst, J. Organometal. Chem., 235 (1982) 77.

2 See for example: M.D. Curtis, L. Messerle, N.A. Fotinos and R.F. Gerlach, Advan. Chem. Soc., 155 (1981) 221.

3 M.H. Chisholm, L.A. Rankel, W.J. Bailey Jr., F.A. Cotton and L.A. Murillo, J. Am. Chem. Soc., 100 (1978) 802.

4 H. Brunner, W. Meier and J. Wachter, J. Organometal. Chem., 210 (1981) C23.

5 R.B. King, M.Z. Iqbal and A.D. King Jr., J. Organometal. Chem., 171 (1979) 53.

6 G.M. Reisner, I. Bernal and G.R. Dobson, J. Organometal. Chem., 157 (1978) 23.

7 P. Niggli, Handbuch der Experimentalphysik, Akademische Verlagsgesellschaft, Leipzig, 1928, p. 108.

8 G.M. Sheldrick, SHELX-76, A Program for Crystal Structure Determinations, Cambridge University, 1976.

9 Unpublished results.

10 F.L. Bowden, R. Giles and R.N. Haszeldine, J. Chem. Soc. Chem. Commun., (1974) 578; R.O. Harris, J. Powell, A. Walker and P.V. Yaneff, J. Organometal. Chem., 141 (1977) 217; D.H.M.W. Thewissen, J. Organometal. Chem., 192 (1980) 115.

11 H. Werner, S. Lotz and B. Heiser, J. Organometal. Chem., 209 (1981) 197.

12 H. Wintergerst, Zulassungsarbeit, Universität Regensburg, 1981.

13 M.H. Chisholm, F.A. Cotton, M.W. Extine and L.A. Rankel, J. Am. Chem. Soc., 100 (1978) 807; M.D. Curtis, K.R. Han and W.M. Butler, Inorg. Chem., 19 (1980) 2096.

14 R.D. Adams, D.A. Katahira and L.-W. Yang, Organometallics, 1 (1982) 231.

15 W. Bertleff and H. Werner, Chem. Ber., 115 (1982) 1012. 